\title{
Angiotensin-converting enzyme (ACE1, ACE2) gene variants are associated with COVID19 severity depending on the hypertension status.
}

Juan Gómez ${ }^{1}$, Guillermo M Albaiceta ${ }^{2,8,9,10,11}$, Marta García-Clemente ${ }^{3}$, Carlos LópezLarrea $^{4,8,9,12}$, Laura Amado-Rodríguez ${ }^{2,8,10,11}$, Tamara Hermida ${ }^{3}$, Ana I. Enriquez ${ }^{3}$, Pablo Herrero $^{5}$, Santiago Melón ${ }^{6}$, Marta E. Alvarez-Argüelles ${ }^{6}$, Susana Rojo-Alba ${ }^{6}$, Alvaro Leal-Negredo $^{6}$, Elías Cuesta-Llavona ${ }^{1}$, Victoria Alvarez ${ }^{1}$, Rebeca Lorca ${ }^{7}$, Eliecer Coto $^{1,, 8,9,12}$

${ }^{1}$ Genética Molecular, Hospital Universitario Central Asturias, Oviedo, Spain.

${ }^{2}$ Unidad de Cuidados Intensivos Cardiológicos, Hospital Universitario Central Asturias, Oviedo, Spain.

${ }^{3}$ Neumología, Hospital Universitario Central Asturias, Oviedo, Spain.

${ }^{4}$ Inmunología, Hospital Universitario Central Asturias, Oviedo, Spain.

${ }^{5}$ Urgencias, Hospital Universitario Central Asturias, Oviedo, Spain.

${ }^{6}$ Microbiologia, Hospital Universitario Central Asturias, Oviedo, Spain.

${ }^{7}$ Cardiología, Hospital Universitario Central Asturias, Oviedo, Spain.

${ }^{8}$ Instituto de Investigación Sanitaria del Principado deAsturias, ISPA, Oviedo, Spain.

${ }^{9}$ Universidad de Oviedo, Oviedo, Spain.

${ }^{10}$ CIBER-Enfermedades Respiratorias. Instituto de Salud Carlos III. Madrid, Spain.

${ }^{11}$ Instituto Universitario de Oncología del Principado de Asturias. Oviedo, Spain.

${ }^{12}$ Red de Investigación Renal (REDINREN), Madrid, Spain.

Correspondenceto:

Dr. Eliecer Coto Hospital Univ. Central Asturias 33011 - Oviedo - Spain

Tel. 34.985.10.55.00

Email: eliecer.coto@sespa.es 


\section{Abstract.}

Background. The Angiotensin system is implicated in the pathogenesis of COVID19. First, ACE2 is the cellular receptor for SARS-COv-2, and expression of the ACE2 gene could regulate the individual's susceptibility to infection. In addition, the balance between ACE1 and ACE activity has been implicated in the pathogenesis of respiratory diseases and could play a role in the severity of COVID19. Functional ACE1/ACE2 gene polymorphisms have been associated with the risk of cardiovascular and pulmonary diseases, and could thus also contribute to the outcome of COVID19.

Methods.We studied 204 COVID19 patients (137 non-severe and 67severe-ICU cases) and 536 age-matched controls. The ACE1 insertion/deletion and ACE2rs2285666 polymorphism were determined. Variables frequencies were compared between the groups by logistic regression. We also sequenced the ACE2 coding nucleotides in a group of patients.

Results. Severe COVID19 was associated with hypertension male gender $(\mathrm{p}<0.001)$, hypertension $(\mathrm{p}=0.006)$, hypercholesterolaemia $(\mathrm{p}=0.046)$, and the ACE1-DD genotype $(\mathrm{p}=0.049)$. In the multiple logistic regression hypertension $(\mathrm{p}=0.02, \mathrm{OR}=2.26$, $95 \% \mathrm{CI}=1.12-4.63)$ and male gender $(\mathrm{p}=0.002 ; \mathrm{OR}=3.15,95 \% \mathrm{CI}=1.56-6.66)$ remained as independent significant predictors of severity. The ACE2 polymorphism was not associated with the disease outcome. The ACE2 sequencing showed no coding sequence variants that could explain an increased risk of developing COVID19.

Conclusions. Adverse outcome of COVID19 was associated with male gender, hypertension, hypercholesterolemia and the ACE1 genotype. The ACE1-I/D was a significant risk factor for severe COVID19, but the effect was dependent on the hypertensive status.

Keywords: COVID19; angiotensin converting enzyme; gene polymorphism; genetic association. 
medRxiv preprint doi: https://doi.org/10.1101/2020.06.11.20128033; this version posted June 12, 2020. The copyright holder for this preprint (which was not certified by peer review) is the author/funder, who has granted medRxiv a license to display the preprint in perpetuity.

It is made available under a CC-BY-NC-ND 4.0 International license .

\section{Introduction.}

The SARS-Cov-2 responsible for the COVID19 pandemic is an Angiotensin I converting enzyme 2 (ACE2)-tropicvirus. Like with the SARS-Cov, the "spike" (S) protein of the new beta-coronavirus binds to the nasopharyngeal mucosa and alveolar pneumocytes that express ACE2 at their surface $(\mathbf{1 , 3})$. The clinical spectrum of this disease, termed COVID19, ranges from mild to very severe cases $\mathbf{( 4 , 5 ) . ~ I t ~ h a s ~ b e e n ~}$ hypothesized that viral infection drives an exacerbated inflammatory response, leading to severe lung injury that may require ICU admission, mechanical ventilation and increases the risk of multi-organ failure and death (6).

The Renin-Angiotensin-Aldosterone system (RAAS) seems to play an important role in the pathogenesis of COVID19 (7). The angiotensin-converting enzyme (ACE1)catalyzes the synthesis of Angiotensin-II (Ang-II) from Ang-I, and ACE2 hydrolyzes Ang-Ilinto Ang-1-7. Ang-II binds to the AT1-receptor driving vasoconstriction, fibrosis, inflammation, thrombosis, among other responses; while Ang-1-7 binds to the AT2-receptor with increased vasodilation and reduced fibrosis, inflammation, and thrombosis. The ACE1 and ACE2 are thus seen as opposite players in the balance that determines the risk of developing hypertension and cardiovascular disease. In the lung, ACE2 drives aprotective response by reducing oedema, permeability and pulmonary damage (8-11). Of note, hypertension and cardiovascular disease are frequent comorbidities in COVID19, and are strongly associated with the risk of hospitalization and death in individuals exposed to SARS-Cov-2 (12-15) (Suppl. figures).

Both, acquired and inherited factors associated with differences in the expression and function of the RAAS components could explain the risk of developing COVID19 and its adverse events. For instance, ACE2 expression in the lungs markedly decreases with age and is greater in men than in women (16). This could explain the higher risk for adverse outcomes in elderly and male. In general, conditions related with a reduced ACE2 expression would increase the risk for hypertension, cardiac hypertrophy, and heart failure (17). In opposition, a high activity of ACE1 would increase the risk of lung and cardiovascular disease by increased activity of the Ang-II/AT1R axis (18). Common variants in the two $A C E$ genes have been associated with the risk of hypertension, heart disease, renal failure, and pulmonary disease. In fact, the ACE1 insertion/deletion (I/D) is one of the best characterised human polymorphisms. 
Individuals with a D/D genotype showed the highest blood ACE1 levels, and this increased expression would explain the higher risk for cardiovascular and respiratory disease among individuals who are deletion-homozygous. This polymorphism has been related with the outcome in acute respiratory distress syndrome (ARDS) by some authors, and also with the progression of pneumonia in SARS (19-22).

The ACE2 gene is on chromosome $\mathrm{X}$ and several single nucleotide polymorphisms (SNPs) have been investigated as risk factors for hypertension and heart failure, including a $\mathrm{G}$ to A change at nucleotide +4 of intron 3 (SNP rs2285666) (23-26). The fact that $A C E 2$ is on chromosome $\mathrm{X}$ has been seen as a disadvantage for male carriers of alleles linked to a lower ACE2 expression, and could explain the higher prevalence of severe COVID19 among males. SARS-CoVdown-regulate myocardial ACE2 expression and this could explain the myocardial inflammation and damage and adverse cardiac outcomes in patients with SARS (27).

Our current knowledge supports a role for the ACE1/ACE2 imbalance in the pathogenesis of COVID19. In this context, variants at these genes associated with differences in gene expression and protein function might explain the individual's predisposition to manifest the disease symptoms and the risk for hospitalization and adverse events. Moreover, some authors have hypothesised that regional differences in allele frequencies could explain the different rate of the incidence and mortality $(\mathbf{2 8 , 2 9})$. Our purpose was to determine whether two common functional ACE1 and ACE2 variants were associated with susceptibility and outcome in COVID19. 
medRxiv preprint doi: https://doi.org/10.1101/2020.06.11.20128033; this version posted June 12, 2020. The copyright holder for this preprint (which was not certified by peer review) is the author/funder, who has granted medRxiv a license to display the preprint in perpetuity.

It is made available under a CC-BY-NC-ND 4.0 International license .

\section{Patients and methods.}

Study cohorts. We collected the anthropometric and clinical data of 204 patients who required hospitalization due to COVID19 (mean age 64.77 years, range 24-95). All the study participants were Caucasian from the region of Asturias (Northern Spain, total population 1 million), and positive for SARS-Cov-2 (PCR test from nasal swabs or tracheobronchial aspirates). Severe cases $(n=53)$ were defined as those in need of critical care support, including high-flow oxygen, positive-pressure ventilation (either invasive or non-invasive) or vasoactive drugs. We also studied 536 healthy population controls matched with the patients for age ( $\mathrm{n}=536$; mean age 70.01 years, range 50-81). The presence of comorbidities (hypertension, diabetes, hypercholesterolaemia) was obtained from the participants medical records. The study was approved by the Ethics Committee of Principado de Asturias (Oviedo, Spain). All the patientsor their representatives gave their consent to participate.

Genotyping. The I/D polymorphism (rs4646994) in intron 16 of the ACE1 gene was genotyped by polymerase chain reaction (PCR) followed by agarose gel electrophoresis to visualise the two alleles, as reported $(\mathbf{3 0 , 3 1})$. For the ACE2rs2285666 A/G SNP the PCR fragments were digested with the restriction enzyme AluI and electrophoresis on agarose gels (Suppl. figures).

ACE2 sequencing. The ACE2 coding exons of 60male patients (30 severe and 30 nonsevere) were amplified with primers designated from exon flanking introns (suppl. tables). These fragments were sequenced with Sanger BigDye chemistry in a capillary ABI3130xl equipment, and the sequences for each patient compared with the ACE2 reference sequence (www.ensembl.org).

Statistical analysis.All the patients and controls data were collected in an excel file and following the requirements of the Ethical Committee. The statistical analysis was performed with the R-project free software (www.r-project.org). The logistic regression (linear generalized model, LGM) was used to compare mean values and frequencies between the groups. 
medRxiv preprint doi: https://doi.org/10.1101/2020.06.11.20128033; this version posted June 12, 2020. The copyright holder for this preprint (which was not certified by peer review) is the author/funder, who has granted medRxiv a license to display the preprint in perpetuity.

It is made available under a CC-BY-NC-ND 4.0 International license .

\section{Results}

Compared to age-matched controls, patients with COVID19 did not differ in the frequency of diabetes, hypertension, and the ACE-DD genotype (table 1). We found a non-significantly lower frequency of hypercholesterolemia in the patients. We compared these variables in severe COVID19 (patients who required mechanical ventilation and/or ICU supportive care) and mild-disease patients. Male sex, hypertension, hypercholesterolemia, and the $A C E$-DD genotype frequencies were significantly higher in the severe group (table 1). The multiple logistic regression-LGM showed that hypertension $(\mathrm{p}=0.02, \mathrm{OR}=2.26,95 \% \mathrm{CI}=1.12-4.63)$ and male gender $(\mathrm{p}=0.002 ; \mathrm{OR}=3.15,95 \% \mathrm{CI}=1.56-6.66)$ remained as independent significant predictors of severity.

We then compared the values in men and women. In men, hypertension, hypercholesterolemia and the $A C E$-DD were significantly increased in severe patients (table 2). The ACE2 rs2285666 alleles did not differ between the two patients groups and were non-significantly higher to the control frequencies. The same analysis performed among female patients revealed no differences between the severe and mild cases, although we observed a trend toward a higher risk for severity among hypertension and hypercholesterolaemia, and a non-significantly higher frequency of the A-allele in the two patients groups compared to controls (table 3). The results in this female cohort would be limited by the reduced size of the severe cohort $(n=14)$.

To better understand the relationship between the two ACE polymorphisms and hypertension, we compared the genotype frequencies between hypertensives and normotensives in male and female patients and controls (supplementary table). In males, the ACE-DD genotype had a higher frequency among hypertensives in the three groups, without statistically significant differences (figure 1). The ACE2-A allele was significantly increased in the hypertensive controls $(21 \%$ vs. $10 \% ; \mathrm{p}=0.02)$, with no significant differences betweensevere and non-severe COVID19 cases. In the female cohort, the DD frequencies did not differ between hypertensive and normotensive in the three groups. The rs2285666 A allele was significantly more frequent among the hypertensive controls $(\mathrm{p}=0.04)$. These results suggested that the $A C E$-DD genotype and ACE2-A carriers could be at a higher risk for hypertension in our population, and genotype and allele differences between the severe and non-severe COVID19 cases could be attribute to their association with hypertension. 
medRxiv preprint doi: https://doi.org/10.1101/2020.06.11.20128033; this version posted June 12, 2020. The copyright holder for this preprint (which was not certified by peer review) is the author/funder, who has granted medRxiv a license to display the preprint in perpetuity.

It is made available under a CC-BY-NC-ND 4.0 International license .

\section{Discussion.}

Since the outbreak of the COVID19 pandemic several authors have speculated about the role of the ACE1 and ACE2 gene polymorphisms in disease susceptibility and severity. Because ACE2 is the SARS-Cov-2 receptor, a functional variant that increased gene expression could be associated with a higher number of membrane-bound viral binding sites, increasing the vulnerability of carriers to infection. These risk variants might be particularly adverse in males, who carry only one copy of X-linked ACE2gene. The ACE2 rs2285666 SNP was in the intronic-consensus splicing nucleotides and could thus affect the processing of ACE2 total RNA to mRNA and, eventually, the amount of the protein. At least one study has reported higher levels of circulating ACE2 levels in men than in women (32). One study has investigated the effect of rs2285666 on serum ACE2 levels, and found significantly higher levels in A-carriers compared to G-homozygotes (33). A different intronic SNPin strong linkage disequilibrium with rs2285666 (rs879922) has been associated with ACE2 gene expression (24). We thus hypothesised that these functionalACE2 variants could modify the disease outcome. In our study, the A-allele frequency was non-significantly higher inpatients vs. controls but was associated with hypertension in both, male and female controls. Lower ACE2 levels should be harmful for patients with lung disease, and the frequency observed in COVID19 patients could thus be the balance between the negative association with viral infection (lower expression in the airway epithelia) and a positive association with respiratory and cardiovascular disease (lower expression in lung and other organs).

The ACE2 A allele has frequencies of 0.15 and 0.19 in our elderly controls. According to the human gene variation databases, this frequency is lower that the reported among unselected Caucasians (0.20-0.25) including the Spanish population (0.24). This lower frequency could be characteristic of our population, but might also reflect a reduction of the lifespan for rs2285666A carriers.

Functional variants in receptors for other viruses confer resistance to infection. One the best characterised is CCR5, the cellular receptor for HIV. A common variant that determines the absence of the receptor (CCR5- $\Delta 32)$ confers a complete resistance to HIV-infection among homozygotes, while reduces the disease progression in heterozygotes. Approximately $1 \%$ of the Caucasians are CCR5- $\triangle 32$ homozygotes and they have a non-significant reduction in lifespan (34). On the contrary, ACE2pathogenic variants are very rare at a population scale, and the complete absence of the receptor 
medRxiv preprint doi: https://doi.org/10.1101/2020.06.11.20128033; this version posted June 12, 2020. The copyright holder for this preprint (which was not certified by peer review) is the author/funder, who has granted medRxiv a license to display the preprint in perpetuity.

It is made available under a CC-BY-NC-ND 4.0 International license .

would be incompatible with life in humans. Moreover, according to the human genome variation databases, there are no common missense changes in the coding ACE2 sequence. At a minor allele frequency $>0.01 \%$ only four missense changes have been reported (all with global frequencies <1\%), and rs2285666 was the only variant that could affect splicing (suppl. tables). We sequenced the exon and intron-flanking sequence in 60 patients and rs2285666 was the only identified variant. Therefore, it is unlikely that the ACE2 coding variants have a significant effect on susceptibility to SARS-Cov-2 infection. Of course, this does not exclude that variants in other gene regions are related with gene expression and the amount of protein.

ACE2 expression is regulated by Ang-II through the AT1R-pathway (35, 36). ACE1 activity could thus modulate the ACE2 expression and activity through the regulation of Ang-II levels. In this scenario the ACE2 gene might be down-regulated in ACE1-DD homozygotes, who have increased ACE1 activity. There are two mechanisms by which functional $A C E 1$ variants could modulate the risk of develop and the clinical outcome of SARS-Cov-2 infection. The reduction of ACE2 expression could protect against viral infection but would also reduce the beneficial effect of ACE2 in the lung and other organs. At the same time, ACEl would enhance the deleterious Ang-II/AT1R response. The ACE1-DD has been associated with and increased risk of respiratory distress system by some authors, but not confirmed by others (20-22). This polymorphism was investigated in 44 Vietnamese SARS cases and 103 healthy controls who had been exposed to SARS-Covand 50 controls without contact with SARS patients (nonexposed) (22). There were no significant differences for DD-frequency among the groups, suggesting that this polymorphism has no effect on the risk for SARS-Cov infection. However, the frequency of the $\mathrm{D}$ allele was significantly higher in hypoxemic than in the non-hypoxemic patients, and could thus contribute to the progression of pneumonia in SARS. In our study we did not find differences for DD-frequencies between COVID19 and controls, thus confirming the lack of association with the risk of developing COVID19 symptoms. However, we did not study individuals exposed who remained asymptomatic and we could thus not exclude an effect in the resistance to viral infection. We found a significant higher risk for a severe form of COVID19 in males. This association was not found among females, although the number of severedisease women was very low $(n=14)$. We confirmed that this genotype was associated with the risk for hypertension in our male controls, with a trend for association with 
medRxiv preprint doi: https://doi.org/10.1101/2020.06.11.20128033; this version posted June 12, 2020. The copyright holder for this preprint (which was not certified by peer review) is the author/funder, who has granted medRxiv a license to display the preprint in perpetuity.

It is made available under a CC-BY-NC-ND 4.0 International license .

hypertension in the patients. Thus, we concluded that the deleterious effect of the ACE1polymorphism on COVID19 outcome was likely due to its association with hypertension.

Male gender, hypertension and hypercholesterolaemia were significantly associated with the risk of developing severe COVID19 in our cohort. The association of adverse outcome with hypertension and sex is well documented. Total Cholesterol and lipoprotein particles might regulate the disease outcome by several ways, including the capacity of the virus to enter the cell membrane and the modulation of the immune response. Hypercholesterolaemia has been associated with COVID19 among Chinese. The study was based on 394 mild, 171 severe, and 32 critical patients, and found significantly lower values of total cholesterol and low-density lipoprotein cholesterol (LDL-Chol) among the critical cases (37). This suggested a protective role for high lipid values in the progression from mild to severe COVID19. We did not confirm this effect. On the contrary, the frequency of hypercholesterolaemia was significantly higher in the severe cases, particularly among male.

Our study has several limitations, mainly the reduced sample size of the patients and of female severe cases in particular. This limits the statistical interpretation of the significant and non-significant associations. Also, we did not study subjects exposed to the virus who did not show disease symptoms. These individuals would be resistant to SARS-Cov-2 infection and are crucial for the identification of gene variants associated with disease susceptibility.

In conclusion, our study suggested that the $A C E$-ID polymorphism was associated with the risk of developing severe COVID19 depending on the hypertension status. The $A C E 2$ rs2285666 variant was associated with hypertension in our elderly population, without significant difference between mild and severe COVID19 patients.

Contributorship. All the authors contributed to this work by recruiting the patients and performing the genetic and statistical analysis. JG, GMA and EC wrote the ms. All the authors approved the submission of this ms.

Competing interests. None of the authors have competing interests related to this work. 
medRxiv preprint doi: https://doi.org/10.1101/2020.06.11.20128033; this version posted June 12, 2020. The copyright holder for this preprint (which was not certified by peer review) is the author/funder, who has granted medRxiv a license to display the preprint in perpetuity.

It is made available under a CC-BY-NC-ND 4.0 International license .

Acknowledgements. This work was supported by a grant from the Spanish Plan Nacional de I+D+I Ministerio de Economía y Competitividad and the European FEDER, grant

ISCIII-Red de Investigación Renal-REDINREN RD16/9/5 (EC). 
medRxiv preprint doi: https://doi.org/10.1101/2020.06.11.20128033; this version posted June 12, 2020. The copyright holder for this preprint (which was not certified by peer review) is the author/funder, who has granted medRxiv a license to display the preprint in perpetuity.

It is made available under a CC-BY-NC-ND 4.0 International license .

Table 1. Main clinical values and genotype frequencies in total patients and controls.

\begin{tabular}{|c|c|c|c|c|c|c|}
\hline & $\begin{array}{c}\text { Severe } \\
\text { Disease } \\
\text { N=67 }\end{array}$ & $\begin{array}{c}\text { Mild } \\
\text { Disease } \\
\mathbf{N = 1 3 7}\end{array}$ & $\mathbf{p}$ & $\begin{array}{c}\text { All } \\
\text { COVID } \\
\text { N=204 }\end{array}$ & $\begin{array}{c}\text { Controls } \\
\text { N=536 }\end{array}$ & p \\
\hline Mean age & 65.76 & 64.56 & 0.53 & 64.96 & 69.88 & AV \\
\hline Male & $53(79 \%)$ & $72(53 \%)$ & $<0.001$ & $125(61 \%)$ & $248(46 \%)$ & AV \\
\hline Hypertensives & $41(61 \%)$ & $56(41 \%)$ & 0.006 & $97(48 \%)$ & $228(43 \%)$ & 0.22 \\
\hline Diabetes & $15(22 \%)$ & $21(15 \%)$ & 0.21 & $36(18 \%)$ & $123(23 \%)$ & 0.13 \\
\hline Hyperchols & $29(43 \%)$ & $40(29 \%)$ & 0.046 & $69(34 \%)$ & $220(41 \%)$ & 0.07 \\
\hline & & & & & & \\
\hline ACE I/D & & & & & & \\
\hline DD & $31(46 \%)$ & $44(32 \%)$ & $0.049 *$ & $75(37 \%)$ & $195(36 \%)$ & $0.92 *$ \\
\hline ID & $31(46 \%)$ & $76(56 \%)$ & & $107(52 \%)$ & $256(48 \%)$ & \\
\hline II & $5(8 \%)$ & $17(12 \%)$ & & $22(11 \%)$ & $85(16 \%)$ & \\
\hline ACE2\# & & & & & & \\
\hline A-carriers & $52(78 \%)$ & $94(69 \%)$ & 0.18 & $146(72 \%)$ & $374(75 \%)$ & 0.33 \\
\hline G & $15(22 \%)$ & $43(31 \%)$ & & $58(28 \%)$ & $124(25 \%)$ & \\
\hline & & & & & & \\
\hline
\end{tabular}

AV: adjust variable, \#498 controls genotyped, A-carriers=maleA and female AA+AG.

* DD vs ID+II 
medRxiv preprint doi: https://doi.org/10.1101/2020.06.11.20128033; this version posted June 12, 2020. The copyright holder for this preprint (which was not certified by peer review) is the author/funder, who has granted medRxiv a license to display the preprint in perpetuity.

It is made available under a CC-BY-NC-ND 4.0 International license .

Table 2.Values in the male patients and controls.

\begin{tabular}{|c|c|c|c|c|c|c|}
\hline \multicolumn{2}{|c|}{ MALE } \\
\hline & $\begin{array}{c}\text { SEVERE } \\
\text { N=53 }\end{array}$ & $\begin{array}{c}\text { MILD } \\
\text { N=72 }\end{array}$ & p & $\begin{array}{c}\text { COVID } \\
\text { N=125 }\end{array}$ & $\begin{array}{c}\text { CONTROL } \\
\text { N=248 }\end{array}$ & p \\
\hline Mean age & 67.19 & 63.89 & 0.13 & 64.77 & 70.01 & AV \\
\hline Hypertensives & $34(64 \%)$ & $26(36 \%)$ & 0.002 & $60(48 \%)$ & $97(39 \%)$ & 0.10 \\
\hline Diabetics & $12(23 \%)$ & $12(17 \%)$ & 0.42 & $24(19 \%)$ & $47(19 \%)$ & 1 \\
\hline Hiperlichols & $25(47 \%)$ & $18(25 \%)$ & 0.01 & $43(34 \%)$ & $82(33 \%)$ & 0.79 \\
\hline & & & & & & \\
\hline ACE2\# & & & & & & \\
\hline G & $43(81 \%)$ & $58(81 \%)$ & 0.92 & $101(81 \%)$ & $200(85 \%)$ & 0.25 \\
\hline A & $10(19 \%)$ & $14(19 \%)$ & & $24(19 \%)$ & $34(15 \%)$ & \\
\hline ACE I/D & & & & & & \\
\hline DD & $28(53 \%)$ & $25(35 \%)$ & $0.043 *$ & $53(42 \%)$ & $85(34 \%)$ & 0.13 \\
\hline ID & $23(43 \%)$ & $43(60 \%)$ & & $66(53 \%)$ & $123(50 \%)$ & \\
\hline II & $2(4 \%)$ & $4(5 \%)$ & & $6(5 \%)$ & $40(16 \%)$ & \\
\hline & & & & & & \\
\hline
\end{tabular}

AV: adjust variable, \#234 male controls genotyped.

$*$ DD vs ID+II 
medRxiv preprint doi: https://doi.org/10.1101/2020.06.11.20128033; this version posted June 12, 2020. The copyright holder for this preprint (which was not certified by peer review) is the author/funder, who has granted medRxiv a license to display the preprint in perpetuity.

It is made available under a CC-BY-NC-ND 4.0 International license .

Table 3. Values in the female patients and controls.

\begin{tabular}{|c|c|c|c|c|c|c|}
\hline \multicolumn{7}{|c|}{ FEMALE } \\
\hline & $\begin{array}{c}\text { SEVERE } \\
\mathrm{N}=14\end{array}$ & $\begin{array}{l}\text { MILD } \\
\mathrm{N}=65\end{array}$ & $\mathbf{p}$ & $\begin{array}{c}\text { COVID } \\
\mathrm{N}=79\end{array}$ & $\begin{array}{c}\text { CONTROL } \\
\text { N=288 }\end{array}$ & $\mathbf{p}$ \\
\hline Mean age & 60.36 & 65.31 & 0.21 & 63.48 & 69.88 & $\mathrm{AV}$ \\
\hline Hypertensives & $7(50 \%)$ & $30(46 \%)$ & 0.79 & $37(47 \%)$ & $131(45 \%)$ & 0.82 \\
\hline Diabetics & $3(21 \%)$ & $9(14 \%)$ & 0.48 & $12(15 \%)$ & $76(26 \%)$ & 0.05 \\
\hline Hiperlipemics & $4(29 \%)$ & $22(34 \%)$ & 0.70 & $26(33 \%)$ & $138(48 \%)$ & 0.02 \\
\hline \multicolumn{7}{|l|}{ ACE2\# } \\
\hline GG & $9(64 \%)$ & $36(55 \%)$ & & $45(57 \%)$ & $174(55 \%)$ & \\
\hline AG & $3(21 \%)$ & $25(38 \%)$ & & $28(35 \%)$ & $81(36 \%)$ & \\
\hline $\mathbf{A A}$ & $2(14 \%)$ & $4(7 \%)$ & & $6(8 \%)$ & $9(9 \%)$ & \\
\hline $\mathbf{A}$ & 0.25 & 0.25 & 0.87 & 0.25 & 0.19 & 0.07 \\
\hline & & & & & & \\
\hline \multicolumn{7}{|l|}{ ACE I/D } \\
\hline DD & $3(21 \%)$ & $19(29 \%)$ & $0.55^{*}$ & $22(28 \%)$ & $110(38 \%)$ & 0.09 \\
\hline ID & $8(58 \%)$ & $33(47 \%)$ & & $41(52 \%)$ & $133(46 \%)$ & \\
\hline II & $3(21 \%)$ & $13(20 \%)$ & & $16(20 \%)$ & $45(16 \%)$ & \\
\hline
\end{tabular}

AV: adjust variable, \#264female controls genotyped.

* DD vs ID+II 
medRxiv preprint doi: https://doi.org/10.1101/2020.06.11.20128033; this version posted June 12, 2020. The copyright holder for this preprint (which was not certified by peer review) is the author/funder, who has granted medRxiv a license to display the preprint in perpetuity.

It is made available under a CC-BY-NC-ND 4.0 International license .

\section{References}

1. Yan R, Zhang Y, Li Y, et al. Structural basis for the recognition of SARS-CoV-2 by full-length human ACE2.Science. 2020; 367 :1444-1448.

2. Shang J, Ye G, Shi K, et al. Structural basis of receptor recognition by SARS-CoV2.Nature. 2020; 581: 221-224.

3. Hoffmann M, Kleine-Weber H, Schroeder S, et al. SARS-CoV-2 Cell Entry Depends on ACE2 and TMPRSS2 and Is Blocked by a Clinically Proven Protease Inhibitor.Cell. 2020; 181: 271-280.e8.

4. Fu L, Wang B, Yuan T, Chen X, et al. Clinical characteristics of coronavirus disease 2019 (COVID-19) in China: A systematic review and meta-analysis.J Infect. 2020; 80: 656-665.

5. Rivieccio BA, Luconi E, Boracchi P, et al. Heterogeneity of COVID-19 outbreak in Italy.Acta Biomed. 2020; 91:31-34.

6. Jose RJ, Manuel A. COVID-19 cytokine storm: the interplay between inflammation and coagulation.Lancet Respir Med. 2020; S2213-2600: 30216-2.

7. Ingraham NE, Barakat AG, Reilkoff $\mathrm{R}$, et al. Understanding the ReninAngiotensin-Aldosterone-SARS-CoV-Axis: A Comprehensive Review. EurResp J. 2000912.

8. Imai Y, Kuba K, Rao S, Huan Y, et al. Angiotensin-converting enzyme 2 protects from severe acute lung failure.Nature. 2005; 436: 112-116.

9. Bao L, Deng W, Huang B, et al. The pathogenicity of SARS-CoV-2 in hACE2 transgenic mice.Nature. 2020; Online ahead of print. 10. AnnoniF, Orbegozo D, Rahmania L, et al. Angiotensin-converting enzymes in acute respiratory distress syndrome.Intensive Care Med. 2019; 45: 1159-1160.

11. Kuba K, Imai Y, Rao S, et al. A crucial role of angiotensin converting enzyme 2 (ACE2) in SARS coronavirus-induced lung injury.Nat Med. 2005; 11: 875-879.

12. Zhou F, Yu T, Du R, et al. Clinical course and risk factors for mortality of adult inpatients with COVID-19 in Wuhan, China: a retrospective cohort study.Lancet. 2020; 395: 1054-1062.

13. Guo T, Fan Y, Chen M, et al. Cardiovascular implications of fatal outcomes of patients with coronavirus disease 2019 (COVID- 19). JAMA Cardiol2020. epub ahead of press. 
medRxiv preprint doi: https://doi.org/10.1101/2020.06.11.20128033; this version posted June 12, 2020. The copyright holder for this preprint (which was not certified by peer review) is the author/funder, who has granted medRxiv a license to display the preprint in perpetuity.

It is made available under a CC-BY-NC-ND 4.0 International license .

14. Shi S, Qin M, Shen B, et al. Association of cardiac injury with mortality in hospitalized patients with COVID-19 in Wuhan, China. JAMA Cardiol2020. Online ahead of print.

15. Bonow RO, Fonarow GC, O'Gara PT, Yancy CW. Association of coronavirus disease 2019 (COVID-19) with myocardial injury and mortality. JAMA Cardiol2020. Online ahead of print.

16. Xie X, Chen J, Wang X, Zhang F, Liu Y. Age- and gender-related difference of ACE2 expression in rat lung.Life Sci. 2006; 78: 2166-2171.

17. Patel VB, Bodiga S, Fan D, Das SK, Wang Z, Wang W, Basu R, Zhong J, Kassiri Z, Oudit GY. Cardioprotective effects mediated by angiotensin II type 1 receptor blockade and enhancing angiotensin 1-7 in experimental heart failure in angiotensinconverting enzyme 2-null mice.Hypertension. 2012; 59: 1195-1203.

18. Wösten-van Asperen RM, Lutter R, Specht PA, et al. Acute respiratory distress syndrome leads to reduced ratio of ACE/ACE2 activities and is prevented by angiotensin-(1-7) or an angiotensin II receptor antagonist.J Pathol. 2011; 225: 618-627.

19. Marshall RP, Webb S, Bellingan GJ, et al. Angiotensin converting enzyme insertion/deletion polymorphism is associated with susceptibility and outcome in acute respiratory distress syndrome.Am J Respir Crit Care Med. 2002; 166:646-650.

20 Matsuda A, Kishi T, Jacob A, et al. Association between insertion/deletion polymorphism in angiotensin-converting enzyme gene and acute lung injury/acute respiratory distress syndrome: a meta-analysis.BMC Med Genet. 2012; 13:76.

21. Villar J, Flores C, Pérez-Méndez L,et al. Angiotensin-converting enzyme insertion/deletion polymorphism is not associated with susceptibility and outcome in sepsis and acute respiratory distress syndrome.Intensive Care Med. 2008; 34: 488-495.

22. ItoyamaS, Keicho N, Quy T, et al. ACE1 polymorphism and progression of SARS. BiochemBiophys Res Commun. 2004; 323: 1124-1129.

23. van derMerwe $L$, Cloete $R$, Revera $M$, et al. Genetic variation in angiotensinconverting enzyme 2 gene is associated with extent of left ventricular hypertrophy in hypertrophic cardiomyopathy. Hum Genet. 2008; 124: 57-61. 
medRxiv preprint doi: https://doi.org/10.1101/2020.06.11.20128033; this version posted June 12, 2020. The copyright holder for this preprint (which was not certified by peer review) is the author/funder, who has granted medRxiv a license to display the preprint in perpetuity.

It is made available under a CC-BY-NC-ND 4.0 International license .

24. Zhang Q, Cong M, Wang $\mathrm{N}$, et al. Association of angiotensin-converting enzyme 2 gene polymorphism and enzymatic activity with essential hypertension in different gender: A case-control study Medicine (Baltimore) 2018; 97: e12917.

25. Lu N, Yang Y, Wang Y, et al. ACE2 gene polymorphism and essential hypertension: an updated meta-analysis involving 11,051 subjects.Mol Biol Rep. 2012; 39: 6581-6589.

26. Chiu RW K, Tang NLS, Hui DSC, et al. ACE2 Gene Polymorphisms Do Not Affect Outcome of Severe Acute Respiratory Syndrome Clin Chem. 2004; 50: 1683-1686.

27.Oudit GY, Kassiri Z, Jiang C, et al. SARS-coronavirus modulation of myocardial ACE2 expression and inflammation in patients with SARS.Eur J Clin Invest. 2009;39: 618-625.

28. Devaux CA, Rolain JM, Raoult D. ACE2 receptor polymorphism: Susceptibility to SARS-CoV-2, hypertension, multi-organ failure, and COVID-19 disease outcome. J Microbiol Immunol Infect. 2020; 53: 425-435.

29. Delanghe JR, Speeckaert MM, De Buyzere ML. COVID-19 infections are also affected by human ACE1 D/I polymorphism. Clin Chem Lab Med 2020; epub ahead of print.

30. Alvarez R, Reguero JR, Batalla A, et al. Angiotensin-converting enzyme and angiotensin II receptor 1 polymorphisms: association with early coronary disease.Cardiovasc Res. 1998;40: 375-379.

31. Coto E, Palacín M, Martín M, et al. Functional polymorphisms in genes of the Angiotensin and Serotonin systems and risk of hypertrophic cardiomyopathy: AT1R as a potential modifier.J Transl Med. 2010; 8: e64.

32. Sama IE, Ravera A, Santema BT, et al. Circulating plasma concentrations of angiotensin-converting enzyme 2 in men and women with heart failure and effects of renin-angiotensin-aldosterone inhibitors.Eur Heart J. 2020; 41:1810-1817.

33.Wu YH, Li JY, Wang C, Zhang LM, Qiao H. The ACE2 G8790A polymorphism: involvement in type 2 diabetes mellitus combined with cerebral stroke. J Clin Lab Anal. 2017; 31:e22033.

34. Alvarez V, López-Larrea C, Coto E. Mutational analysis of the CCR5 and CXCR4 genes (HIV-1 co-receptors) in resistance to HIV-1 infection and AIDS development among intravenous drug users.Hum Genet. 1998; 102: 483-486. 
medRxiv preprint doi: https://doi.org/10.1101/2020.06.11.20128033; this version posted June 12, 2020. The copyright holder for this preprint (which was not certified by peer review) is the author/funder, who has granted medRxiv a license to display the preprint in perpetuity. It is made available under a CC-BY-NC-ND 4.0 International license.

35. XiaoL, Haack KKV, Zucker IH. Angiotensin II regulates ACE and ACE2 in neurons through p38 mitogen-activated protein kinase and extracellular signal-regulated kinase 1/2 signaling. Am J Physiol Cell Physiol. 2013; 304: C1073-C1079.

36. Koka V, Huang XR, Chung ACK, et al. Angiotensin II Up-Regulates Angiotensin I-converting Enzyme (ACE), but Down-Regulates ACE2 via the AT1-ERK/p38 MAP Kinase Pathway. Am J Pathol. 2008; 172: 1174-1183.

37. Wei X, Zeng W, Su J, Wan et al. Hypolipidemia is associated with the severity of COVID-19. J Clin Lipidol. 2020; 30: S1933-2874(20)30078-7. 
medRxiv preprint doi: https://doi.org/10.1101/2020.06.11.20128033; this version posted June 12, 2020. The copyright holder for this preprint (which was not certified by peer review) is the author/funder, who has granted medRxiv a license to display the preprint in perpetuity.

It is made available under a CC-BY-NC-ND 4.0 International license .
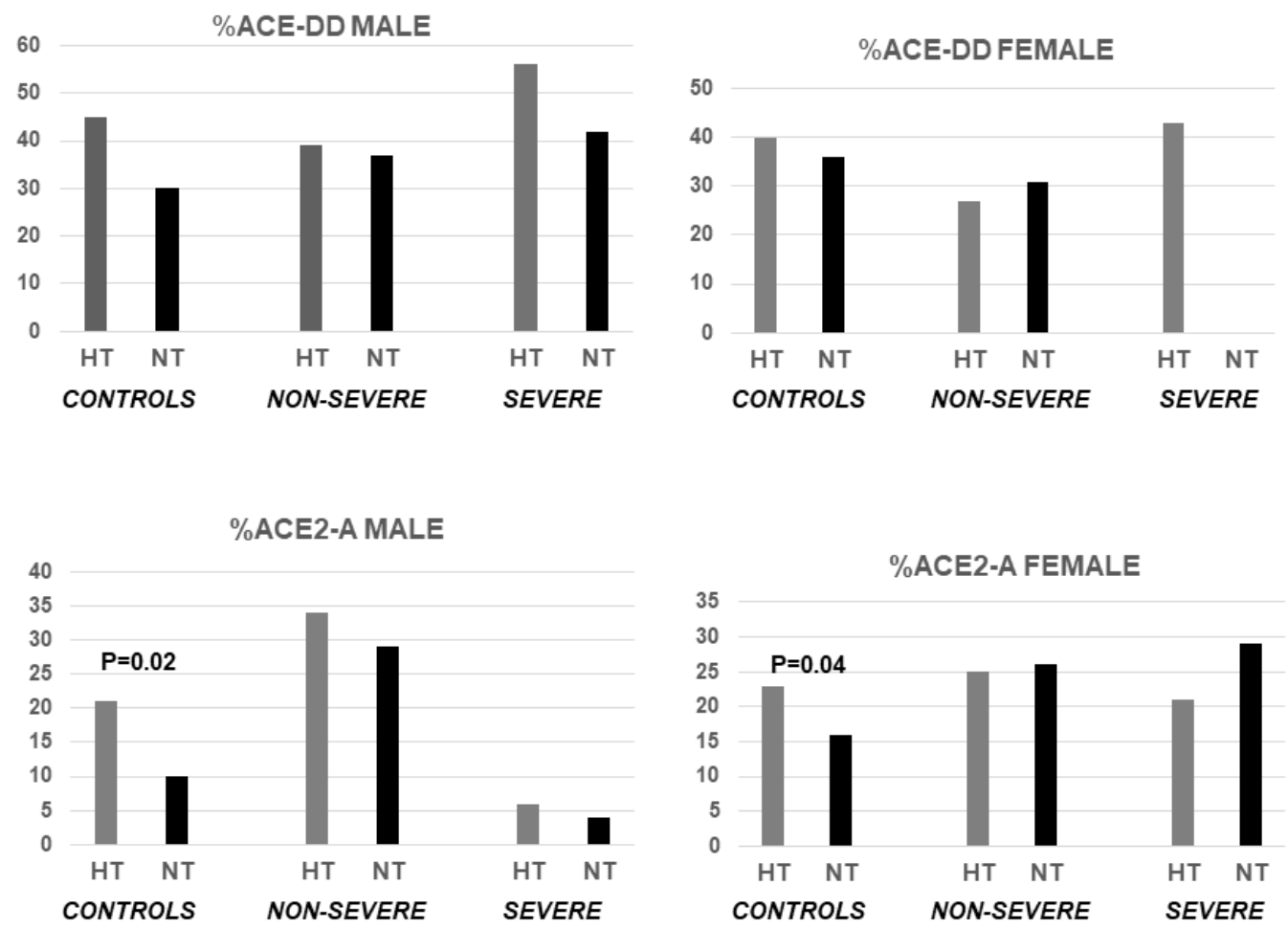

Figure 1. ACE1 and $A C E 2$ genotype frequencies according to sex and hypertension. 
medRxiv preprint doi: https://doi.org/10.1101/2020.06.11.20128033; this version posted June 12, 2020. The copyright holder for this preprint (which was not certified by peer review) is the author/funder, who has granted medRxiv a license to display the preprint in perpetuity.

It is made available under a CC-BY-NC-ND 4.0 International license .

Supplementary table. Primers for amplification and sequencing the ACE2 coding exons.

\begin{tabular}{|ll|}
\hline ACE2-2F & GGC CAT AAA GTG ACA GGA GAG GTA AG \\
\hline ACE2-2R & GGG ATA TGG AGG CAA ACA TCC AAT CTC \\
\hline ACE2-3F & GTG GCC TGG TCA CTC TTA ACC TAA AC \\
\hline ACE2-3R & GGA CAC CTT ACC TAG GCA TAG AGA G \\
\hline ACE2-4F & GTG CTT ATA GTA CTT TGT GCT AGT CGA C \\
\hline ACE2-5R & GAG GAC ATG ATT GTT AAT TGA GGG GTA TC \\
\hline ACE2-6F & ATTTCTTTTAACCTCCCAGCAAGGCTAATC \\
\hline ACE2-7R & GCT TTC AAA ATG CGA TTT CTA CAA TGT TAC TAA CC \\
\hline ACE2-9F & CTG TAA CCA CCA TTC TAC TCT CTG CTT C \\
\hline ACE2-10R & CCA GTA GTA ATT TCC AGT TAC CCA TAA ATA CC \\
\hline ACE2-12F & GAT TGA TGA AAC TGC ACT AGT TAT GCC C \\
\hline ACE2-14R & GGT GCT CAA CAG TTG TGA TTT TTC TCC C \\
\hline ACE2-16F & CTT ACA TTG AAG GTC ACT GAC TTA ATG AAT AGC \\
\hline ACE2-17R & GCA TGA GGT AAC ACA TGT AAA TGA CTC AGA \\
\hline ACE2-19F & ATT GCC CTC AAT AGC GGC TGT ACC \\
\hline ACE2-19R & GCC AGG AGC CCC AGA CAC TCA \\
\hline
\end{tabular}


medRxiv preprint doi: https://doi.org/10.1101/2020.06.11.20128033; this version posted June 12, 2020. The copyright holder for this preprint (which was not certified by peer review) is the author/funder, who has granted medRxiv a license to display the preprint in perpetuity.

It is made available under a CC-BY-NC-ND 4.0 International license .

Supplementary table. Distribution of the ACE1 and ACE2 genotypes in patients and controls according to the sex and hypertension.

\begin{tabular}{|c|c|c|c|c|c|c|}
\hline & \multicolumn{2}{|c|}{$\begin{array}{c}\text { MALE } \\
\text { CONTROLS }\end{array}$} & \multicolumn{2}{|c|}{$\begin{array}{l}\text { MALE } \\
\text { MILD }\end{array}$} & \multicolumn{2}{|c|}{$\begin{array}{c}\text { MALE } \\
\text { SEVERE }\end{array}$} \\
\hline & $\begin{array}{c}\text { Hypertens } \\
\mathrm{N}=89\end{array}$ & $\begin{array}{c}\text { Normotens } \\
\mathrm{N}=145\end{array}$ & $\begin{array}{l}\text { Hypertens } \\
N=26\end{array}$ & $\begin{array}{c}\text { Normotens } \\
\mathrm{N}=46\end{array}$ & $\begin{array}{c}\text { Hypertens } \\
N=34\end{array}$ & $\begin{array}{c}\text { Normotens } \\
\mathrm{N}=19\end{array}$ \\
\hline ACE-DD & $40(45 \%)$ & $44(30 \%)$ & $10(39 \%)$ & $17(37 \%)$ & $19(56 \%)$ & $8(42 \%)$ \\
\hline ACE-I+ & $49(55 \%)$ & $101(70 \%)$ & $16(61 \%)$ & $29(67 \%)$ & $15(44 \%)$ & $11(58 \%)$ \\
\hline $\begin{array}{c}\text { P } \\
\text { DD vs I+ }\end{array}$ & \multicolumn{2}{|c|}{0.06} & \multicolumn{2}{|c|}{0.88} & \multicolumn{2}{|c|}{0.33} \\
\hline ACE2-A & $19(21 \%)$ & $15(10 \%)$ & $9(34 \%)$ & $5(29 \%)$ & $6(17 \%)$ & $4(19 \%)$ \\
\hline ACE2-G & $70(79 \%)$ & $130(90 \%)$ & $17(66 \%)$ & $12(71 \%)$ & $28(83 \%)$ & $15(81 \%)$ \\
\hline p A vs G & \multicolumn{2}{|c|}{0.02} & \multicolumn{2}{|c|}{0.72} & \multicolumn{2}{|c|}{0.52} \\
\hline
\end{tabular}

\begin{tabular}{|c|c|c|c|c|c|c|}
\hline & \multicolumn{2}{|c|}{$\begin{array}{c}\text { FEMALE } \\
\text { CONTROLS }\end{array}$} & \multicolumn{2}{|c|}{$\begin{array}{c}\text { FEMALE COVID } \\
\text { MILD }\end{array}$} & \multicolumn{2}{|c|}{$\begin{array}{c}\text { FEMALE COVID } \\
\text { SEVERE }\end{array}$} \\
\hline & $\begin{array}{c}\text { Hypertens } \\
\mathrm{N}=131\end{array}$ & $\begin{array}{c}\text { Normotens } \\
\mathrm{N}=157\end{array}$ & $\begin{array}{c}\text { Hypertens } \\
N=30\end{array}$ & $\begin{array}{c}\text { Normotens } \\
\mathrm{N}=35\end{array}$ & $\begin{array}{c}\text { Hypertens } \\
\mathrm{N}=3\end{array}$ & $\begin{array}{c}\text { Normotens } \\
\mathrm{N}=19\end{array}$ \\
\hline ACE-DD & $53(40 \%)$ & $57(36 \%)$ & $8(27 \%)$ & $11(31 \%)$ & $3(43 \%)$ & 0 \\
\hline ACE-I & $78(60 \%)$ & $100(64 \%)$ & $22(73 \%)$ & $24(69 \%)$ & $4(57 \%)$ & $7(100 \%)$ \\
\hline $\begin{array}{c}P \\
\text { DD vs I+ }\end{array}$ & \multicolumn{2}{|c|}{0.47} & \multicolumn{2}{|c|}{0.67} & \multicolumn{2}{|c|}{0.07} \\
\hline ACE2-AA & $7(6 \%)$ & $2(1 \%)$ & $1(3 \%)$ & $3(9 \%)$ & 0 & $2(29 \%)$ \\
\hline ACE2-AG & $40(33 \%)$ & $41(29 \%)$ & $13(43 \%)$ & $12(34 \%)$ & $3(43 \%)$ & 0 \\
\hline ACE2-GG & $73(61 \%)$ & $101(70 \%)$ & $16(54 \%)$ & $20(57 \%)$ & $4(57 \%)$ & $5(71 \%)$ \\
\hline ACE2-A & 0.23 & 0.16 & 0.25 & 0.26 & 0.21 & 0.29 \\
\hline p A vs G & \multicolumn{2}{|c|}{0.04} & \multicolumn{2}{|c|}{0.92} & \multicolumn{2}{|c|}{0.99} \\
\hline
\end{tabular}


medRxiv preprint doi: https://doi.org/10.1101/2020.06.11.20128033; this version posted June 12, 2020. The copyright holder for this preprint (which was not certified by peer review) is the author/funder, who has granted medRxiv a license to display the preprint in perpetuity.

It is made available under a CC-BY-NC-ND 4.0 International license.

Supplementary table. ACE variants with reported global minor allele frequency (MAF) $>0.1 \%$

\begin{tabular}{|l|l|l|l|l|}
\hline SNP id rs & nucleotide & effect & MAF Europeans & MAFSpain \\
\hline rs2285666 & c.439+4 G>A & $\begin{array}{l}\text { Intron, } \\
\text { splicing? }\end{array}$ & 0.24 & 0.25 \\
\hline rs4646116 & c.77 A $>$ G & p.Lys26Arg & $<0.01$ & $<0.01$ \\
\hline rs149039346 & c.2074 T>C & p.Ser692Pro & 0 & 0 \\
\hline rs41303171 & c.2158 A $>$ G & p.Asn720Asp & 0.02 & 0.02 \\
\hline rs147311723 & c.2191 C>T & p.Leu731Phe & 0 & 0 \\
\hline
\end{tabular}




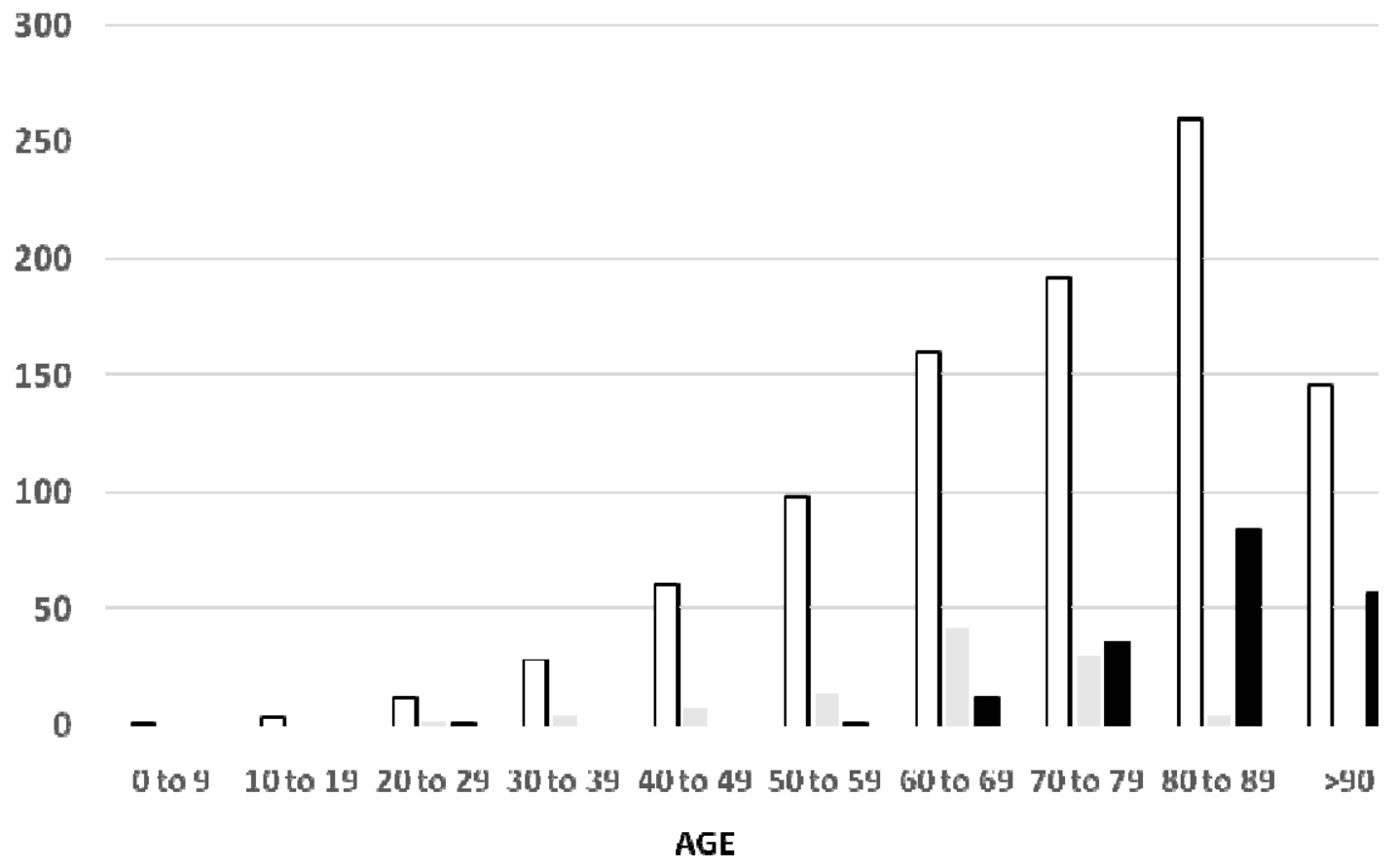

\section{MILD SEVERE UCI QDEATH}

Suppl figure. Total number of COVID19 individuals with mild disease, severe-ICU, and deaths in the region of Asturias (population 1 million), according to the age-range. Data released April 14 2020.

Total COVID19 cases, laboratory confirmed: 2,331 (women 1,362).

Non-severe hospitalised: 961 (women, 481).

Severe-UCI: 103 (women, 31).

Death: 191 (women, 103).

Source: Asturias Government, https://obsaludasturias.com/obsa/wp-content/uploads/ COVID-19 Asturias Situacion 20200419.pdf 
medRxiv preprint doi: https://doi.org/10.1101/2020.06.11.20128033; this version posted June 12, 2020. The copyright holder for this preprint (which was not certified by peer review) is the author/funder, who has granted medRxiv a license to display the preprint in perpetuity.

It is made available under a CC-BY-NC-ND 4.0 International license .

\section{comorbidities}

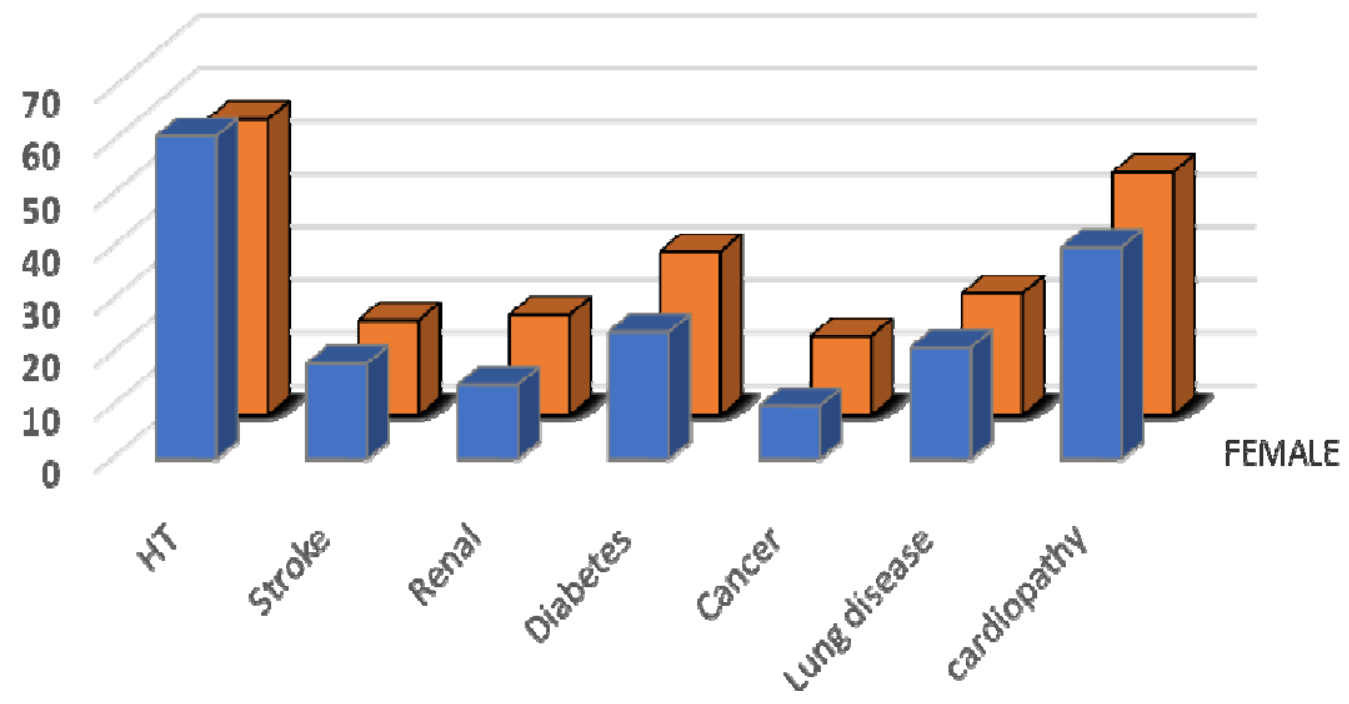

Suppl figure. Number of cases with comorbidities among the COVID19 deaths in the region of Asturias, male (blue) and female (orange). Data released April $14^{\text {th }} 2020$.

HT: hypertension, Renal: reduced renal function. 
medRxiv preprint doi: https://doi.org/10.1101/2020.06.11.20128033; this version posted June 12, 2020. The copyright holder for this preprint (which was not certified by peer review) is the author/funder, who has granted medRxiv a license to display the preprint in perpetuity.

It is made available under a CC-BY-NC-ND 4.0 International license .
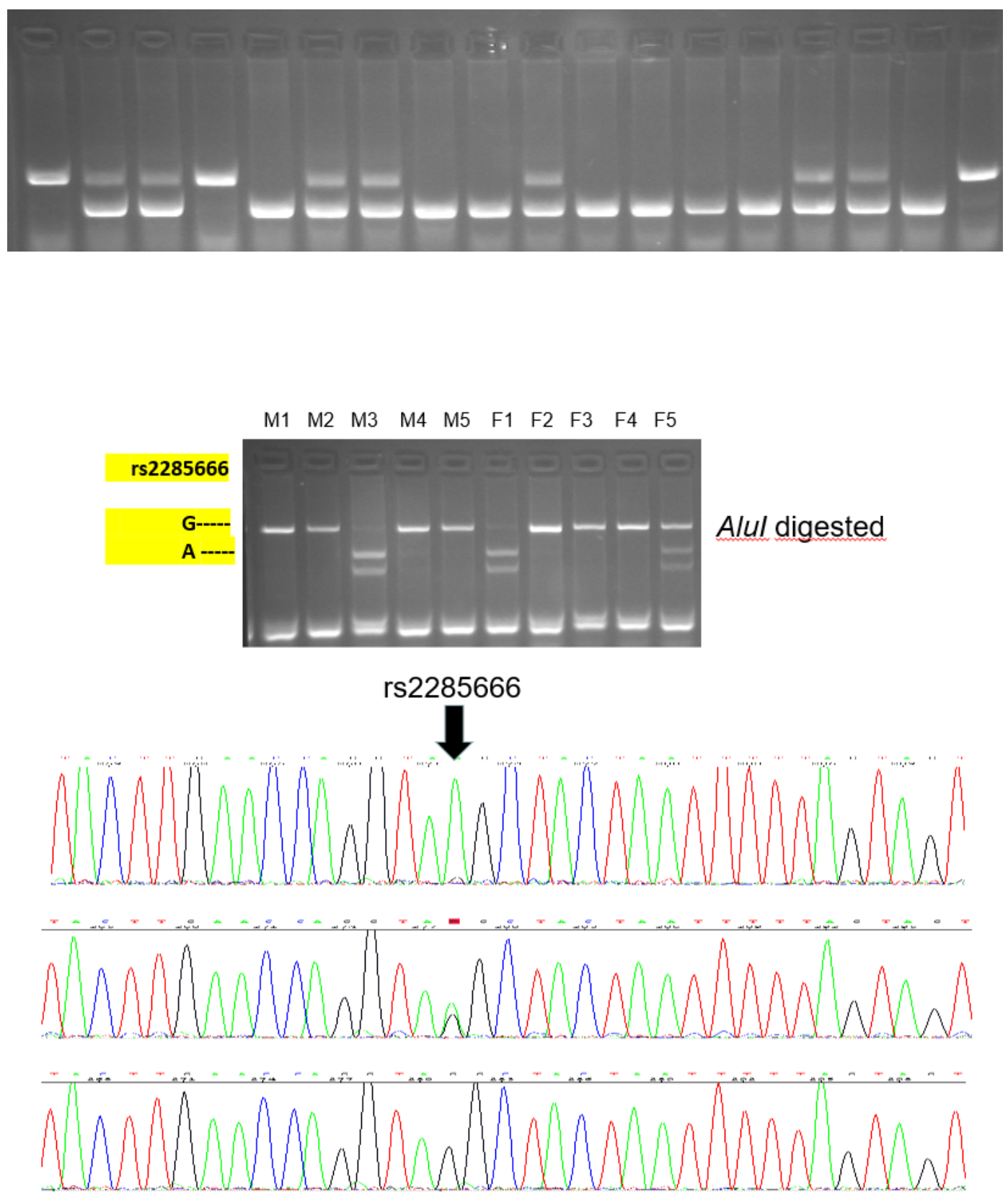

Suppl. Figure. Above: ACE1 AD genotype of 18 individuals. Agarose gel electrophoresis of PCR fragments.

Below: Agarose gel electrophoresis of 5 male (M) and 5 female (F) for the ACE2 SNP. Capillary electrophoresis of three ACE2 genotypes, showing the SNP (arrow). 